\title{
College and University Library News, 1942-43
}

Mr. Reece is professor of library service at Columbia University.

$\mathrm{T}$

HE NINETEENTH periodic compilation of items relating to college and university libraries appears in the pages that follow. ${ }^{3}$ As in the past, the effort is to present a truthful picture rather than an exhaustive one. On the whole the news is less copious than in some years, although the reports of accessions stand up well in volume and developments growing out of the war compensate in no small measure for meagerness at other points. The scantiness appears particularly in the cases of notable exhibits, money gifts, consideration of purposes and functions, technical procedures, buildings, and organizational work on the part of librarians. Some of

Abbreviations used in footnotes: A.A.C.B.-Association of American Colleges Bulletin; A.L.A.B.A.L.A. Bulletin; C.\&R.L. College \& Research LiLraries; J.H.E.-Journal of Higher Education; L.J.- Publishers' Weekly; S.\&S. School and Society; W.L.B.-Wilson Library Bulletin.

1 The students who helped to gather material are: Sue J. Billings, Jean P. Curry, Lois P. Curry, Alice M. Delehanty, Marga Franck, Helen E. Goess, Clayton M. Hall, Elizabeth G. Lindsey, Elizabeth G. McKernan, Marie S. Pike, Erna L. Russo, Katherine H. Schwartz, Nancy W. Stirling, Susanna P. Zwemer. 2 The series of which this summary is the latest has been sponsored largely by the Conference of Eastern College Librarians at Columbia University. The present article was read by title at the meeting on Jan. 29, 1944. It is based primarily on material appearing in publications issued between Nov. I, 1942 , and Oct. 31,1943 , inclusive.

3 Recent resumes were published in College and Research Libraries 4:107-14, 127, March 1943; in Library Journal 66:1075-81, Dec. I5, 1941; and for the years up to 1940 as shown in the article and listing in Library Journal 65:1071-77, Dec. 15, 1940. it may be due less to a paucity of significant occurrences than to conditions in which depleted staffs are too pressed to report on the interests and activities of their libraries.

Whatever the benefactions of other sorts, there is no marked slackening in the gifts of books and collections. Harvard acquired Arthur Houghton's and John Gregory's Keats material, 3000 of Philip Hofer's books on the graphic arts, 8000 William James manuscripts, I05 volumes from Herman Melville's library, and quantities of matter associated with Gamaliel Bradford VI, Oliver Wendell Holmes, and Ralph Waldo Emerson. ${ }^{4}$ M.I.T. received early Diderot encyclopedias; ${ }^{5}$ Bowdoin, 300 volumes from E. Parmalee Prentice's classic collection on agriculture ; ${ }^{6}$ Amherst, the library of Professor Wendell T. Bush of Columbia ; and Brown, additions to the Harris American poetry and plays, ${ }^{8}$ a number of Bolivar letters and other manuscripts of American interest, ${ }^{9}$ and sundry items from the Providence Government Research Bu-

4 Harvard University. Library Report. . . I941-42, p. 2 -5. dent's Report, I941-42, p. 59 .

${ }^{6}$ Bowdoin College. 'President's Report, 1942-43, p.

${ }^{32}$ i Amherst College Library. Report of Director ..., $1941-42$, p. 2.

8 Brown University. Librarian. Annual Reports, 1940-4I and $1941-42$, p. 19.

9 C.\&R.L. $4: 262$. 
reau. ${ }^{10}$ Dartmouth's "Friends" supplied it with a variety of pieces, including notable typescripts and first editions of contemporary and recent authors. ${ }^{11}$ Wesleyan secured further material from the Johnston map collection. ${ }^{12}$

Yale continued its gift record with the Frear Mark Twain accumulation, ${ }^{13}$ the Coe Western manuscripts, ${ }^{14}$ the 25,000 Hillhouse items, ${ }^{15}$ the Lambert material relating to Isaac Walton and Charles Cotton, ${ }^{16}$ the 366 Winthrop miniatures, ${ }^{17}$ several Eugene O'Neill manuscripts, ${ }^{18}$ and numerous other important collections and pieces. ${ }^{19}$ Columbia received the 2000 bound and 4000 unbound volumes on social legislation of Samuel McCune Lindsay, ${ }^{20}$ the Park Benjamin Knickerbocker literature and an accompanying group of manuscripts and first editions, ${ }^{21}$ considerable Boas material relating to the American Indian, ${ }^{22}$ and further Coykendall first editions of English poetry. ${ }^{23}$ New York University added much of the Adkins library of American literature ${ }^{24}$ and a variety of microfilms, including some of manuscripts dealing with the early history of American colleges and universities. ${ }^{25}$

To Princeton there came new pieces from the Garrett collection, ${ }^{26}$ eleven

10 Brown University. Librarian. Annual Reports, I $940-4 \mathrm{I}$ and r $94 \mathrm{I}-42$, p. I8.

${ }_{11}$ Dartmouth College. Library Bulletin 4:30-31.

12 Wesleyan University. Libracy. About Books

I 3:6-7.8.R.L. 4:I68; Yale University Library Gazette I $7: 59 ;$ I $8: 1-5$.

14 C.\&R.L. $4: 262$

16 Ibid: $4: 168 ;$ Yale University Library Gazette 17 : 45-47.

1 7:6I-65.

55-56.

18 Yale University Library Gazette $18: 5-8$.

19 Ibid. I $7: 54-60,85-88$; $18: 15-18,35-38$.

${ }^{20}$ C.\&R.L. $4: 84$; W.L.B. $17: 337$.

21 Information from unpublished sources.

22 Information from Acquisitions Department of $\mathrm{Co}$

lumbia University Libraries.

28 Ibid.

${ }^{21}$ Society for the Libraries of New York Univer.

sity Bulletin, Mar. I943, p. I-2.

${ }_{25}$ Ibid., p. 3-4.

${ }_{20}$ Princeton University Library Chronicle 4:5-9. manuscripts of Eugene O'Neill's dramas, ${ }^{27}$ a number of sixteenth century items, ${ }^{28}$ and specimens of Japanese and Hindu records. $^{29}$ Bryn Mawr gained early scientific works which once belonged to Professor Benjamin A. Gould, of Harvard, together with rarities from other sources. ${ }^{30}$ Swarthmore was enriched by the MurrayBringhurst letters, ${ }^{31}$ and Penn State by the 5000 Robert H. Hay volumes, notable for their attention to American experimental colonies and lesser religious groups. ${ }^{32}$

Johns Hopkins acquired as a gift a vellum manuscript of A.D. $1350,^{33}$ and Duke a significant Whitman collection. ${ }^{34}$ There were made over to Kentucky the books and records of the Louisville printing firm of J. P. Morton and the Confederate material treating the war record of General John Hunt Morgan. ${ }^{35}$ Texas Christian obtained the James R. Curtis music library $;^{36}$ and Trinity of Texas, subsequent to its merger with the University of San Antonio, several welcome donations. ${ }^{37}$

Ira S. Wile's important library on sociology and related sciences was given to Rochester, ${ }^{38}$ as were also the Irving items belonging to Mrs. C. Schuyler Davis. ${ }^{39}$ Hamilton received a polyglot $\mathrm{Bible}$, a $\mathrm{He}$ brew commentary, and ancient Egyptian artifacts. $^{40}$ Michigan added fifteen in-

27 Ibid, $4: 86-89$

$28 \mathrm{Ibid}$. 4:I $4 \mathrm{I}$.

20 Ibid.

30 Bryn Mawr College. Report of the President, I 94 I - 42 , p. 35.

32 C. $68: 8: 262$

33 Johns Hopkins University Library. Ex Libris, v. I 2 , no. 4 , June 1943

9 C. \&R.L. 4:329; A.A.C.B. $29: 300$.

35 C.\&R.L. $4: 329$

36 Ibid. $4: 169$

37 Ibid. $4: 264$

38 C.\&R.L. 4:262; University of Rochester. Li. brary. Fortnightly Bulletin, v. 22, no. 7, Sept. 25, ${ }^{1943}$ C. \&R.L. $4: 84$; University of Rochester. Library. Fortnightly Bulletin, v. 22, no. 7, Sept. 25, I 943.

40 Hamilton College. Library. Annual Report, I 94 I-42, p. 3. 
cunabula and various other benefactions which are moderate in size but important, ${ }^{41}$ and to its Clements Library the William Vernon Smith Indian material. ${ }^{42}$ Northwestern received the collection assembled by Mr. and Mrs. Charles G. Dawes $;^{43}$ Milwaukee-Downer Mrs. G. E. White's 4000 volumes relating to art, travel, and Shakespeare; ${ }^{44} \mathrm{~W}$ isconsin the Wight accumulation pertaining to France ${ }^{45}$ Drake 5000 sheet music scores for band, orchestra, and choir $;^{46}$ and Minnesota manuscripts of the composer Brescia. ${ }^{47}$ Scripps gained by the receipt of the 6000 pieces belonging to the late John I. Perkins, including rarities; ${ }^{48}$ and Stanford's Business School by adding records of the Pacific Improvement Company. ${ }^{49}$ Abroad, the Bodleian continued to gather in early books, documents, and autographs, its acquirements embracing Bacon items, Oriental manuscripts, and diversified pieces produced by a salvage drive..$^{50}$

\section{Non-Gift Additions}

Gratifying as are the donations, there have been notable additions which are not reported as in that class. Princeton came into possession of an Arabic book of hours, ${ }^{51}$ and Rochester arranged to receive early works on medicine from the Boston Medical Library, in exchange for a group of Paris theses. ${ }^{52}$ Michigan acquired thirteen incunabula and various early classical editions. ${ }^{53}$ Swarthmore gained

\footnotetext{
41 University of Michigan. President's Report, I $94 \mathrm{I}-42$, p. $244,248$.

${ }_{43}$ Northwestern University. President's Report, I 94 I-42, p. 23.

${ }_{44}$ C.\&R.L. $4: 85$

45 Ibid. $4: 265$.

46 Iowa Library Quarterly I $4:$ I 26.

48 A.A.C.B. $28: 490-9 \mathrm{I}$.

40 C.\&R.L. $4: 86$.

50 Bodleian Library Record $2: 72-83$

51 Princeton University Library Chronicle $4: 5-9$.

52 University of Rochester. Library. Fortnightly Bulletin, v. 22, no. 7, Sept. 25, 1943 .

${ }^{53}$ University of 'Michigan. President's Report, I 94 I-42, p. 248 .
}

diversified items relating to the Society of Friends; $;^{54}$ and Lebanan Valley the Heilman library, with its valuable German and early American imprints. ${ }^{55}$ Fairleigh Dickinson Junior College bought at auction the 4000 volumes belonging to Arlington Hall Junior College, whose plant has been taken for war uses. ${ }^{56}$ Johns Hopkins added three apparently unpublished Lieber letters. ${ }^{57}$ North Carolina continued to build its Latin American collection $;^{58}$ while Texas acquired 400 nineteenth century dime novels $;^{59}$ and California James Westfall Thompson's medieval history material and W. S. Kuno's collection relating to $\mathrm{Japan}^{60}$ The Bodleian bought several sets of letters, including Selden correspondence. ${ }^{61}$ A recent study of research resources in Virginia libraries, while not a product of I942-43, was reviewed within the year. ${ }^{62}$

Although they are not numerous, several money gifts promise to contribute in part to book resources. J. M. McCandless put $\$ \mathrm{IO}, 000$ at the disposal of Emory in honor of his mother, the income to be spent in the field of education $;^{63}$ and Goucher received pledges amounting to $\$ 5000$ for books in memory of Anne K. Robertson. ${ }^{64}$ Cornell accepted from the Rockefeller Foundation \$I 8,ooo to gather and preserve upstate New York cultural source material. ${ }^{65}$ Forty-five thousand dollars were added to the Doane endowment at Denison, ${ }^{66}$ and $\$ 50,000$ announced to set up a trust fund for book

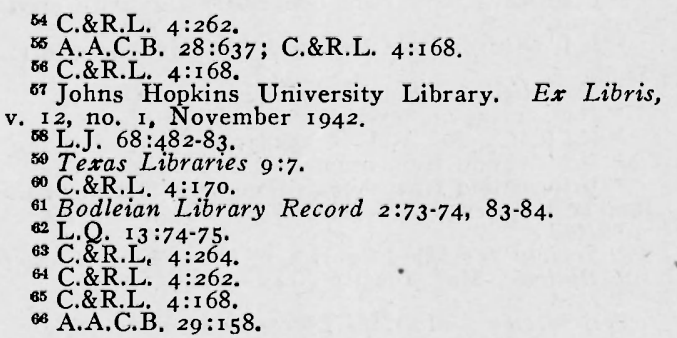


purchases at Knox. ${ }^{67}$ Rochester is in receipt of money for first editions of eighteenth century English authors. ${ }^{68}$ Indiana was given funds to enlarge its Lincoln collection. ${ }^{69}$ Two hundred and fifty pounds were left to the Bodleian for volumes relating to the fine arts. ${ }^{70}$ The benefactions of the Carnegie Corporation to college libraries in recent years, although not news of 1943, were collectively described by Barcus. ${ }^{71}$

What is being done with and for library collections may be as important as the collections themselves. Indiana made its Oakleaf Lincoln material available, ${ }^{72}$ and Lincoln Memorial is devoting a room to items pertaining to the Civil War and to Lincoln. ${ }^{73}$ Bryn Mawr instituted a rare book room, ${ }^{74}$ while Drake opened a reference library of sheet music. ${ }^{75}$ Cataloging progress was reported from Penn State, where considerable work has been done on the Pattee library of American literature, ${ }^{76}$ and from Georgia, which has a General Education Board appropriation for general recataloging. ${ }^{77}$ New Hampshire inaugurated a browsing room, with a reader's adviser in attendance ${ }^{78}$ and Kutztown Teachers College in Pennsylvania was able to give results of a year's experience with a browsing collection. ${ }^{79}$ New Hampshire also organized circulating libraries in fraternity houses. ${ }^{80}$ Community services were described as being

\footnotetext{
67 Ibid. 29:301; J.H.E. 1 4:103-04.

68 C. \&R.L. $4: 84$

69 Ibid $4: 265$

70 Bodleian Library Record 2:7 I.

${ }^{71}$ Barcus, T. R. Carnegie Corporation and College Libraries, 1938-43, 1943; C.\&R.L. 4:323-24. ${ }_{72}$ Library Occurrent $14: 124$ : C.\&R.L. $4: 265$.

${ }^{73}$ C.\&R.L. $4: 264$.

${ }^{74}$ Bryn Mawr College. Report of the President, $194 I=42$, p. 39.

${ }_{75}$ Iowa Library Quarterly $14: 126$.

${ }^{76}$ C.\&R.L. $4: 328$.

T. Ibid. $4: 328-29$.

78 Journal of Home Economics 35:226-27.

79 L.J. $68: 439$.

80 University of New Hampshire. Report of the President, 1942, p. $84-85$.
}

offered by various colleges for Negroes, ${ }^{81}$ and generous rural facilities by $T$ alladega. ${ }^{82}$ Mayville State Teachers College in North Dakota also was portrayed as circulating books to the countryside. ${ }^{83}$ Southwestern of Memphis made films on Latin America available off the campus. ${ }^{84}$ New Hampshire has undertaken book reviewing over a Portsmouth radio station. ${ }^{80}$

Such facilities as are mentioned above have been supplemented by fresh arrangements and devices at some points. Swarthmore has tried a browsing room offering of selected books from the stacks and unlimited loans for the titles reserved in connection with honors work. ${ }^{86}$ Dartmouth has adopted new display and circulating provisions for timely books. ${ }^{87}$ Carleton has instituted an "extended loan" plan, ${ }^{88}$ and Florida State conducted a campaign to advertise its government publications. ${ }^{89}$ The Graduate School of Public Administration at Harvard has developed a novel system for filing the press releases of war agencies. ${ }^{90}$ Cundiff dealt with the care and use of sound recordings, in an article indicating that such materials are coming to be widely employed in college teaching $;^{91}$ and Tichenor treated service with instructional materials in a teachers college library. ${ }^{92}$

Exhibits presumably have been utilized as formerly for promoting services, yet relatively few libraries indicate special dependence upon them. North Carolina arranged displays for Pan-American week; $;^{93}$

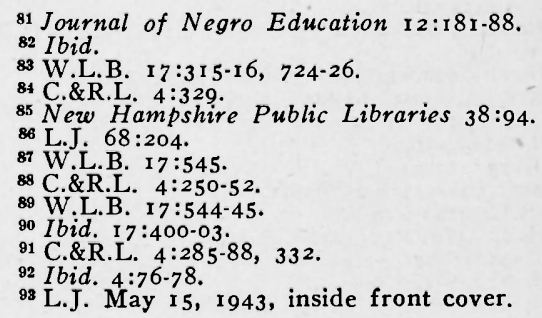


Columbia gathered for view early kindergarten textbooks from its Plimpton collection $;^{94}$ and Colby Junior helped in sponsoring a book fair. ${ }^{95}$

For the moment at least the purposes and position of libraries seem to be expressed more in acts than in words. However, the Second Work Conference on Higher Education at Sewanee formulated conclusions as to the role of college libraries in higher institutions ; ${ }^{96}$ Hoole addressed another meeting on making libraries serve the teaching process $;^{97}$ the educational place of junior college libraries was considered from several angles $;^{98}$ and the service areas of teachers college libraries were taken up by two authors. ${ }^{99}$ The North Central Association launched a survey of college and university libraries. ${ }^{100}$ As pointing to past, present, and future, an interesting trilogy appeared in Stewart's article on the sources of American college library history, ${ }^{101}$ in Johnson's account of measures to further relations with Latin America, ${ }^{102}$ and in Davidson's glance toward years ahead. ${ }^{103}$

\section{Administrative Problems}

Some attention was manifest within the year to the lines and principles of organization commonly accepted by students and experts on the subject. Statements as to the schemes of organization at California, ${ }^{104}$ Harvard, ${ }^{105}$ and Texas ${ }^{106}$ were followed by a discussion of them by Henkle. ${ }^{107}$ Realignments recently put into

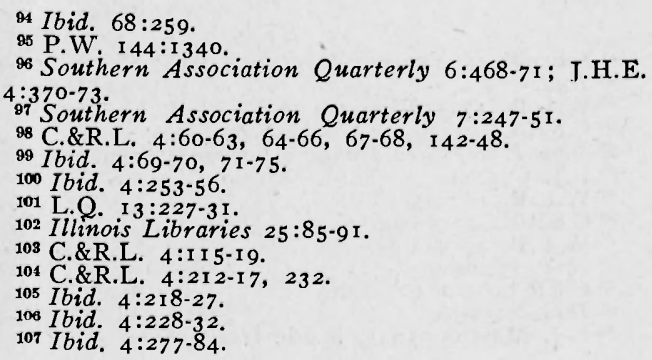

effect at Illinois ${ }^{108}$ and Maryland ${ }^{109}$ were noted. Hanson reviewed several plans bearing on the choice between centralized and departmentalized systems. ${ }^{110}$ Initiation of a department of printed books was reported from the Bodleian. ${ }^{111}$

Administrative problems other than those of organizational form have received generous treatment. Haverford, Swarthmore, and Bryn Mawr explored the possibilities of cooperation ;12 two conferences elsewhere dealt with means for it $;^{113}$ while the Pacific Northwest Bibliographical Center brought toward fruition its particular effort in this direction. ${ }^{114}$ The Penn State staff studied systematically the administration of its own library. ${ }^{115}$ Interest in service received notice in Reed's plea for more adequate reference work $;^{116}$ in the review of Daniel's study of the needs and interests of Negro freshmen $;^{117}$ and in the response by Hiram to the call for training for teacher librarians. ${ }^{118}$ Suggestions regarding collections came in a Muhlenburg study of what use is made of books after they reach the shelves $;^{119}$ in Gosnell's thesis on obsolescence $;^{120}$ and in a proposal as to means of evaluation. ${ }^{121}$ Borrowers' eligibility was defined at Arkansas ;122 Battles and associates ${ }^{123}$ and Knapp working alone ${ }^{124}$ studied circulation routines and

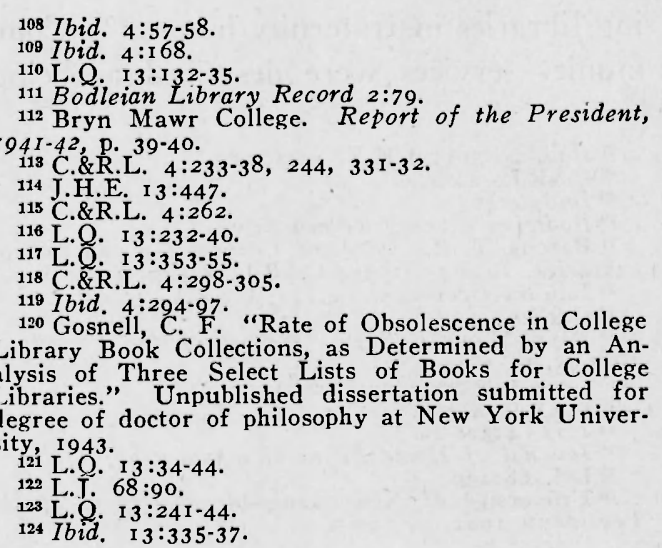


preparations costs respectively; Kerr discussed the professorial view of a card catalog $;^{125}$ and Stokes took up the creation of demand for services. ${ }^{126}$ The staffs of the chemistry and physics library at Penn State essayed to relieve faculty members of some of the work of surveying the literature bearing on their war projects. ${ }^{127}$ Van Hoesen set forth in an entertaining way the problems raised by well-meaning "Friends." 128 The Association of College and Reference Libraries, with aid from the American Library Association office, produced the annual statistics of college and university libraries $;^{129}$ and the United States Office of Education gave out its consolidated I940 figures. ${ }^{130}$

Building operations are reported from a few places, although they have fallen off sharply. New homes for their libraries were added by Macalester, ${ }^{131}$ Davidson, ${ }^{132}$ and St. Mary's of Indiana. ${ }^{133}$ Presbyterian of South Carolina, possibly following the Chattanooga example, achieved one jointly with the city of Clinton; $;^{134}$ and the Carroll dedication took place. ${ }^{135}$ The McMurray ${ }^{136}$ and the University of South Carolina ${ }^{137}$ buildings were described, as was also the one proposed for Queens in New York. ${ }^{138}$ Northwestern received Mr. and Mrs. Charles G. Dawes' home, presumably to house a collection provided by the same donors $;^{139}$ and Washington Square Library of New

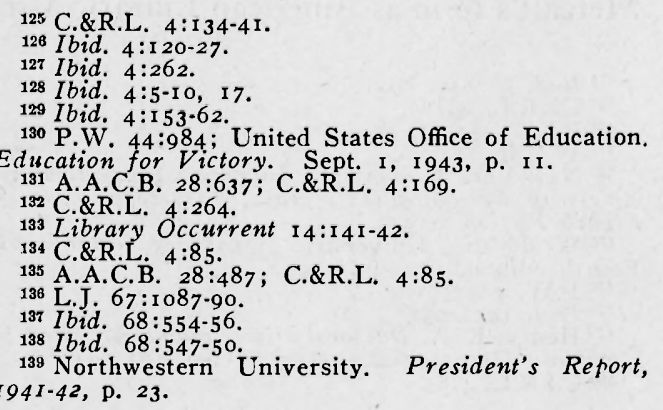

York University moved its main stock and facilities from the tenth to the first floor of the college building in which they long have been quartered. ${ }^{140}$

\section{Effects of War}

War effects on libraries cumulate as the national effort intensifies. Welch traced them back to the changes forced upon the colleges, from which in part they take their rise. ${ }^{141}$ Brown, ${ }^{142}$ Orne, ${ }^{143}$ and Ver Nooy $^{144}$ pictured the possible contributions of libraries in the emergency, and Stewart ${ }^{145}$ and Hirsch ${ }^{146}$ treated the exigencies faced at the liberal arts colleges. Little's article on activities dealt to some extent with the securing and financing of needed acquisitions, ${ }^{147}$ toward which it may be added that New York University's “Friends" appropriated \$200, earmarked for technical books. ${ }^{148}$

Actual war activities grew more and more diversified, as revealed by Little's thoroughgoing report ${ }^{149}$ upon them and otherwise. The widespread centers have become marked by special attention to pamphlets and government publications, ${ }^{150}$ by the displaying and distributing of popular war books, ${ }^{151}$ by the stocking and showing of films, ${ }^{152}$ by the sponsoring of radio programs, ${ }^{153}$ by enhanced use of microfilm copies of periodicals, ${ }^{154}$ and by the issue of a pamphlet to make informa-

\footnotetext{
140 Society for the Libraries of New York Univer. sity Bulletin, March I 943 , p. 7.

141 Illinois Libraries 25:56-59.

142 Iowa Library Quarterly I 4 : I I 8-20.

143 Illinois Libraries 25:1 I-I 4 .

144 Ibid. 25:14-16.

145 L.J. $67: 1093-96$

${ }^{146} \mathrm{Ibid}$. 68:192-95.

147 C.\&R.L. $4: 197-2$ I I

$1+8$ Society for the Libraries of New York Univer. sity Bulletin, March I $943, \mathrm{p} .3$.

140 C.\&R.L. 4:179-2II ; A.L.A.B. $37: 179-82$.

${ }_{150}$ C.\&R.L. $4: 194-95$; A.L.A.B. $37: 181 ;$ Purdue University. Report of the President, I94I-42, p. I 23.

${ }_{152}$ C. University of Rochester. Library. Fortnightly Bulletin, v. 22, no. 7, Sept. 25, 1943; Texas Library Association. News Notes, April 1943, p. 2 I. 153 C.\&R.L. $4: 202-03$.

154 United States Office of Education. Education for Victory, July I 5, I 943 , p. 21.
} 
tion services known. ${ }^{155}$ Facilities were extended to Army, Navy, and auxiliary branches $^{156}$ and include the assignment of building space, ${ }^{157}$ opportunities for research, ${ }^{158}$ lengthening of hours of opening, ${ }^{159}$ instruction in the use of libraries, ${ }^{160}$ and availability of collections of records and of light fiction. ${ }^{161}$ General and typical descriptions of war contributions have been provided by Christoffers, ${ }^{162}$ Thompson, ${ }^{163} \quad$ Knollenberg, ${ }^{164}$ and Kampenga. ${ }^{165}$

Staff dislocations multiply. Osborn dealt both with those due to decreased demands and with those attributable to shortage of help. ${ }^{\mathbf{1 6 6}}$ Other writers reported the recruiting of girls as pages as well as in clerical capacities, ${ }^{167}$ the discovery of competent workers among the wives of language students, ${ }^{168}$ and the supplementing of staff members by volunteers. ${ }^{169}$

Agreement seems approaching on the financial basis for library service to the armed forces at college training centers. Early in the year Charles H. Brown discussed this as well as other issues entailed in library operation at such centers ; ${ }^{\mathbf{1 7 0}}$ and more recently a correspondence between American Library Association officers and Secretary Stimson foreshadowed improved

${ }^{155}$ New Mexico Library Bulletin, November 1942, p. $2-3$.

Association. 4:190; A.L.A.B. 37:181; Texas Library News Notes, April 1943, p. 19-20; Louisiana Library Association. Bulletin, March 1943, p. 15 ; C.\&R.L. $4: 190-9 \mathrm{I}$

${ }_{157}$ Texas Library Association. News Notes, April 1943, p. I9-20; C.\&R.L. 4:I68, i 90. ${ }_{158}$ C. \&R.L. 4:19-20, i $85-90$.

160 Texas Library Association. News Notes, April 1943, p. 20; C.\& R.L. 4:190-9I.

${ }_{100}$ L.J. 68:645-48; C.\&R.L. 4 : 19 I-92.

161 C.\&R.L. 4:190-9I.

162 Ibid. $4: 18: 24$

103 Ibid. $4:$ II I I

$10+$ Ibid. $4: 25-28$

165 Ibid. $4: 79-83$

106 W.L.B. I 8:43.

167 L.J. $67: 918-19$; W.L.B. $18: 53$

108 W.L. B. I $8: 53$.

169 C.\&R.L. $4: 329$

170 L.J. $68: 333$.

understandings, for one military arm at least. ${ }^{171}$

\section{Publications}

The number of publications by libraries and librarians is modest. It is of interest, however, that Hampton began its periodical Notes, ${ }^{172}$ and that at Michigan there appeared the first number of the occasional Quarto. ${ }^{173}$ Western Reserve issued a list entitled Twenty-Five Books on Inter-American Relations; ${ }^{174}$ New York University produced a fifth section of its Index to Early American Periodical Literature $;^{175}$ and Wesleyan published a fourth edition of its Handbook. ${ }^{176}$ Carl Weber of Colby edited a group of Edwin Arlington Robinson letters ; ${ }^{\mathbf{1 7 7}}$ and Colton Storm of the Clements Library has been assisting the Bowker company with American Book Prices Current. ${ }^{178}$ Publications attributable to organizations are the tenth list of American dissertations, ${ }^{179}$ produced under the auspices of the Association of Research Libraries; and two compilations emanating from the conference of Colorado college librarians, one listing the periodicals received by college libraries in the state and one the course offerings, by subject, in the several educational institutions represented. ${ }^{180}$

In organizational work college and university librarians apparently have been less active than in some years. Keyes D. Metcalf's term as American Library Asso-

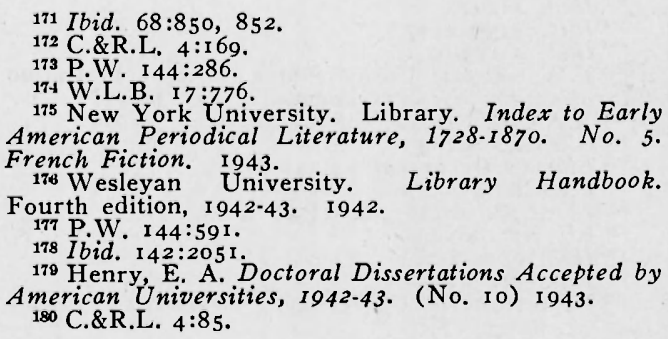


ciation president expired and he was succeeded by a leader from the public library field. ${ }^{181}$ J. H. Lancaster of Heidelberg served as a vice president of the Ohio Library Association. ${ }^{182}$

\section{Personnel Changes}

There have been a number of important retirements. They include those of $\mathrm{C}$. C. Williamson at Columbia, ${ }^{183}$ Frank $\mathrm{K}$. Walter at Minnesota, ${ }^{184}$ John C. French at Johns Hopkins, ${ }^{185}$ Mary E. Baker at Tennessee, ${ }^{186}$ and Betty Pritchett at Coe;187 and, among teachers colleges, Sadie Kent at Southeast in Missouri ${ }^{188}$ and Odella Nation at Pittsburg in Kansas. ${ }^{189}$ Lewis Stieg resigned at Hamilton to assume the assistant directorship at the University of Illinois Library School. ${ }^{190}$ The losses by death that have come to notice are those of William A. Alexander of Indiana, ${ }^{191}$ Walter $B$. Briggs of Harvard, ${ }^{192}$ and Carrie $M$. Watson, librarian emerita at Kansas. ${ }^{193}$

Undoubtedly scores of members of college and university library staffs are in service with the armed forces. The list is known to include such names from the higher ranks as those of J. Periam Danton, ${ }^{194}$ Oscar C. Orman, ${ }^{195}$ Ralph H. Parker, ${ }^{196}$ John Mackenzie Cory, ${ }^{197}$ Jerrold Orne, ${ }^{198}$ and Boniface E. Moll. ${ }^{199}$

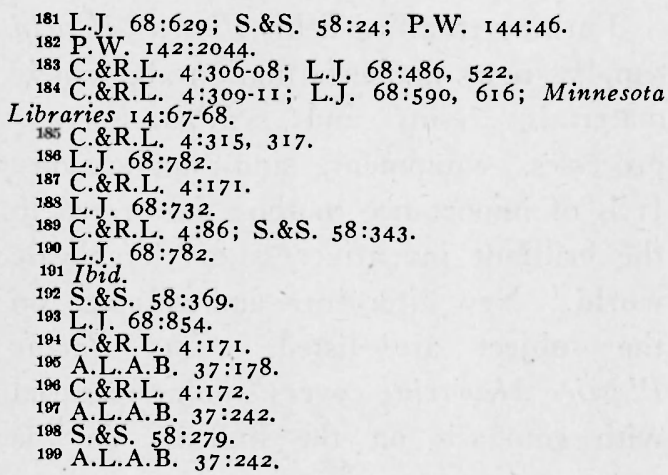

Partly because of the retirements previously mentioned, notable appointments have been fairly numerous. Carl $M$. White went to the head position at Columbia, ${ }^{200}$ Robert B. Downs to Illinois, ${ }^{201}$ E. W. McDiarmid, Jr., to Minnesota, ${ }^{202}$ Harriet D. MacPherson to Smith, ${ }^{203}$ Homer Halvorson to Johns Hopkins, ${ }^{204}$ William $\mathrm{H}$. Jesse to Tennessee, ${ }^{205}$ Alan R. Laursen to Knox, ${ }^{206}$ and Lewis C. Branscomb to South Carolina ;207 while William $\mathrm{H}$. Carlson became associate librarian at Washington, ${ }^{208}$ Mrs. Emily Miller Danton acting librarian at Temple ${ }^{209}$ and $\mathrm{J}$. Isaac Copeland acting librarian at Presbyterian of South Carolina. ${ }^{210}$ Alice L. Hoskinson took charge at Rockford, ${ }^{211}$ Elizabeth Windsor at Coe, ${ }^{212}$ Janet Agnew at Sweet Briar, ${ }^{213}$ Wendell W. Smiley at Mercer, ${ }^{214}$ Eva Wrigley at Furman, ${ }^{215}$ William P. Tucker at Macalester, ${ }^{216}$ and Stella M. Robbins at William Penn. ${ }^{217}$

Head posts in junior colleges were filled by Lois E. Engleman, who went to Colby Junior, ${ }^{218}$ and by $H$. Margaret Hardin at Frances Shimer in Illinois. ${ }^{219}$ In the libraries of teachers colleges and normal schools, Gretchen Westervelt became head at Potsdam in New York (Continued on page I6o)

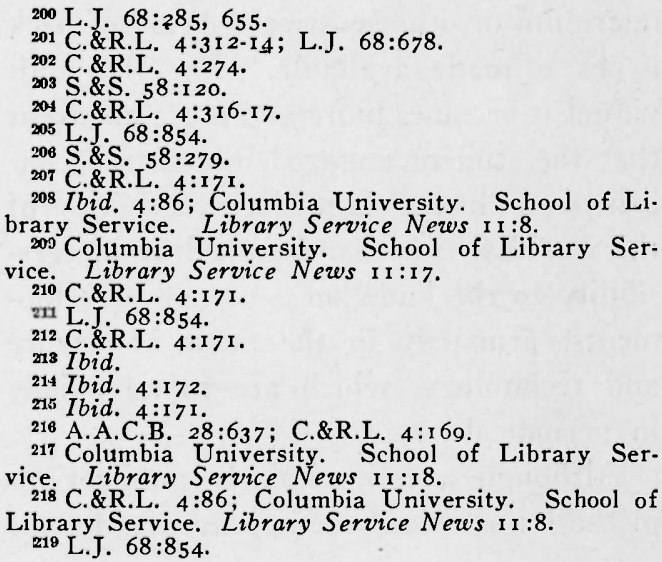

